\title{
Catch-and-release angling as a management tool for freshwater fish conservation in India
}

\author{
Nishikant Gupta, Prakash Nautiyal, Atul Borgohain, K. Sivakumar \\ Vinod B. Mathur and Michael A. Chadick
}

\begin{abstract}
Mahseer are popularly regarded by anglers as the king of freshwater fishes, and are valued across the Himalayan and South-east Asian regions. In India, mahseer are important game fish. Mahseer populations and their habitats face a range of anthropogenic threats, however, including unregulated fishing and habitat fragmentation as a result of hydro-development projects. Catch-and-release angling for mahseer attracts both national and international anglers and could provide information about rivers while generating revenue for regional economies. In this context, we evaluated catch-and-release angling records from rivers that flow within two Indian reserves (the Ramganga and Jia Bharali Rivers in Corbett and Nameri Tiger Reserves, respectively). Golden mahseer Tor putitora in the Ramganga and golden and chocolate mahseer Neolissochilus hexagonolepis in the Jia Bharali were the most frequently caught fish species. Catch data suggested these game fish populations are probably not negatively affected by angling activities. Interviews with stakeholders highlighted support for catch-and-release angling, mainly because of its perceived economic benefits. The data obtained in this research could potentially assist with both fish conservation and the protection of associated aquatic ecosystems.
\end{abstract}

Keywords Assam, Corbett, Jia Bharali, Nameri, Ramganga, recreational angling, river conservation, Uttarakhand

\section{Introduction}

$\mathrm{R}$ iver fishes provide a range of ecological functions and services. Some species control trophic structure and others indicate the environmental health of a river system (Sarkar \& Bain, 2007; Schindler, 2007). Fish provide a protein source for many communities in developing countries (Lakra et al., 2007), offer recreation through

Nishikant Gupta (Corresponding author) and Michael A. Chadwick Department of Geography, King's College London, London, WC2R 2LS, UK E-mail nishikantgupta@live.in

Prakash NaUtiYal Department of Zoology, H.N.B. Garhwal University, Srinagar, Uttarakhand, India

Atul Borgohain Assam Agricultural University, Khanapara, Guwahati, Assam, India

K. Sivakumar and Vinod B. Mathur Wildlife Institute of India, Chandrabani, Dehradun, India

Received 26 May 2014. Revision requested 2 July 2014.

Accepted 29 August 2014. First published online 10 November 2014. catch-and-release angling (Pinder \& Raghavan, 2013), and potentially act as flagship species for conservation (Gupta et al., 2014). However, the growing human population and ever increasing demand for water result in water pollution, flow modification, destruction of habitats and invasion by non-native species, and degrading of fish stocks (Everard \& Kataria, 2011; Jena \& Gopalakrishnan, 2012), and reduce the range and degree of services provided by river fish.

In India fish have not received the same level of conservation attention as more visible, terrestrial species (Pinder $\&$ Raghavan, 2013). Policies for fish conservation have suffered from formulation and implementation delays as a result of poor management practices (Sarin, 2005; Ribot \& Agrawal, 2006), and community-based conservation has struggled to protect rivers outside village jurisdiction (Gupta, 2013). At a federal level, no freshwater fishes are listed in the Schedules of Protected Species in the Indian Wildlife (Protection) Act, 1972 (Sarkar et al., 2008). There is a clear need, however, to formulate and implement conservation strategies to protect freshwater fishes and their habitats (Pinder \& Raghavan, 2013).

Catch-and-release angling (i.e. capturing using rod and reel, and releasing fish, as a leisure activity) could be widely offered through region-specific environmental guidelines. This type of angling is a popular leisure activity and could provide benefits to local stakeholders (Pereira et al., 2008). For example, a 5-day angling tour for three anglers on the Ramganga River, India, in 2007 generated USD 1,220, and in the same location in 2010 anglers spent USD 7,800 on food and accommodation (Everard \& Kataria, 2011). Catch-and-release angling also generates income for other national economies. In Alaska catch-and-release angling generates USD 1 billion annually (Zwirn et al., 2005). Catch-and-release angling for the yellowfish (Labeobarbus spp.) in the Orange Vaal River, South Africa, is valued at USD 160 million annually (Impson et al., 2008). In the right setting, the provision of catch-and-release angling is a stable and profitable undertaking (Arismendi \& Nahuelhual, 2007).

Along with economic benefits, catch-and-release angling can enhance conservation (Arlinghaus, 2006; Granek et al., 2008; Pinder \& Raghavan, 2013). For example, the Deccan mahseer Tor khudree populations in the Cauvery River, South India, are protected by associations among local stakeholders and catch-and-release anglers (Pinder \& Raghavan, 2013). Catch-and-release anglers can also provide important information to assist conservation via reporting 
of fishing effort and data on fish caught (e.g. species identifications, individual length \& mass), which are typically recorded in logbooks kept by fishing clubs and individual anglers (McGarvey et al., 2005; Cooper, 2006). Such data can also aid scientists and policy makers in the design of management actions.

Mahseer are of angling interest because of their renowned fighting abilities and are regarded by anglers as the king of freshwater fishes (mahseer refers to fish of the genera Tor, Neolissochilus and Naziritor in the family Cyprinidae). Two popular mahseer in India, the golden mahseer Tor putitora and chocolate mahseer Neolissochilus hexagonolepis, face threats from activities such as poaching and the construction of barrages and dams (Nautiyal et al., 2013; Pinder \& Raghavan, 2013). These species receive some protection, however, in the Ramganga and Jia Bharali Rivers in the Indian Himalayan region where the rivers flow through the Corbett and Nameri Tiger Reserves.

The aim of this research was to examine the potential of catch-and-release angling as a monitoring and management tool for the protection of mahseer in the Ramganga and Jia Bharali rivers. These rivers were of special interest because they are within the legislatively defined boundaries of tiger reserves and may thus receive indirect protection, and there are recreational catch data for 1999-2012 for both rivers. Our specific objectives were to evaluate catch-and-release data for mahseer species, and to investigate the opinions of stakeholders towards catch-and-release angling and its potential as a management tool.

\section{Study area}

The Ramganga is a perennial river originating at $800-900 \mathrm{~m}$ altitude in the north-west of Almora district in Uttarakhand. In 2004 local angling associations obtained a lease from the Uttarakhand Forest Department for a $24 \mathrm{~km}$ length of the Ramganga River within Corbett Tiger Reserve. The goal of the angling associations was to protect mahseer populations through catch-and-release angling. During 2004-2011 catch-and-release angling increased on the Ramganga, attracting both national and international anglers, resulting in economic benefits for some local stakeholders (Everard \& Kataria, 2011). In July 2012 catch-and-release angling within all protected areas was halted by the Supreme Court of India (Ajay Dubey vs National Tiger Conservation Authority (special leave petition no(s).21339/2011)). The order was to safeguard tiger Panthera tigris habitats by halting human activities within tiger reserves. The catch-and-release angling associations located on the Ramganga were directly affected as all angling was banned within the boundaries of Corbett Tiger Reserve. However, catch-and-release angling is still permitted on reaches of the Ramganga River outside Corbett Tiger Reserve, and this is where the majority of foreign and Indian anglers visiting the region now fish.

The Jia Bharali is a major tributary of the Brahmaputra River, with c. $30 \mathrm{~km}$ lying within the Nameri National Park. Catch-and-release angling permits were issued for the river through the Assam (Bhoralli) Angling and Conservation Association. As on the Ramganga, all catch-and-release angling was banned within the Park boundary in 2012.

\section{Methods}

Catch data for fish caught by national and international catch-and-release anglers during 1999-2012 were obtained from the logbooks of angling associations on the Ramganga and Jia Bharali Rivers. The logbooks include total number and weight of fish caught (Table 1) and unsuccessful angling events. Catch-and-release angling events generally lasted for 1 hour, whether successful or not (catch-and-release angling guides, pers. comms). In all cases these data were willingly provided by the angling associations (the Mahseer Conservancy and the Himalayan Outback on the Ramganga River, and the Assam (Bhoralli) Angling and Conservation Association on the Jia Bharali River).

The catch per unit of fishing effort (CPUE; number of fish caught/number of hours angling) was calculated for the most frequently landed fish. A one-way ANOVA was used to test whether there were differences in CPUE and mean weight of individual species across years. It was not possible to assess differences between rivers because of gaps in the data for individual species and annual variations in fishing effort on the Jia Bharali River.

We conducted semi-structured interviews with stakeholders near Corbett Tiger Reserve and the Ramganga River during 2012-2013. Interviews were not conducted in Nameri Tiger Reserve because of logistical constraints. The aim of these interviews was to explore themes related to catch-and-release angling, in particular conservation benefits for fish, the availability of economic incentives, and conservation concerns. Interviewees were identified as conservationists (individuals generally opposed to angling, blaming it for harming river habitats and wanting to see stricter enforcement of guidelines for angling), people directly associated with angling (Indian catch-and-release anglers and catch-and-release angling association workers) or local people (residing along the Ramganga River). The interviewees were sampled based on their availability during the field survey, their willingness to participate, their residence in villages near the Ramganga River, and whether they had an association with local catch-and-release angling. The total number of responses obtained for each group depended on the approachability of individuals and their availability and willingness to participate. The $15-30$ minute interviews were conducted during 9.00-17.00. 
TABLE 1 Summary of catch records from the catch-and-release angling log books of the Mahseer Conservancy, Himalayan Outback and Jia Bharali angling associations for the Ramganga and Jia Bharali rivers, with the total number of golden mahseer Tor putitora landed, total number of hours spent angling, catch per unit effort (CPUE), and total number of other fish landed (including chocolate mahseer Neolissochilus hexagonolepis).

\begin{tabular}{|c|c|c|c|c|c|c|c|c|}
\hline \multirow[b]{2}{*}{ Year $^{*}$} & \multicolumn{4}{|c|}{ Ramganga River } & \multicolumn{4}{|l|}{ Jia Bharali River } \\
\hline & $\begin{array}{l}\text { No. of golden } \\
\text { mahseer }\end{array}$ & $\begin{array}{l}\text { No. of hours } \\
\text { angling }\end{array}$ & CPUE & No. of other fish & $\begin{array}{l}\text { No. of golden } \\
\text { mahseer }\end{array}$ & $\begin{array}{l}\text { No. of hours } \\
\text { angling }\end{array}$ & CPUE & No. of other fish \\
\hline 1999-2000 & & & & & 18 & 107 & 0.17 & $\begin{array}{l}62 \text { chocolate mah- } \\
\text { seer, } 7 \text { Raiamas spp. }\end{array}$ \\
\hline \multicolumn{9}{|l|}{ 2000-2001 } \\
\hline \multicolumn{9}{|l|}{ 2001-2002 } \\
\hline $2002-2003$ & & & & & 12 & 38 & 0.33 & 14 chocolate mahseer \\
\hline 2003-2004 & & & & & 30 & 67 & 0.45 & 7 chocolate mahseer \\
\hline 2004-2005 & 12 & 28 & 0.43 & 0 & & & & \\
\hline 2005-2006 & 4 & 18 & 0.22 & 0 & & & & \\
\hline 2006-2007 & 12 & 47 & 0.26 & 0 & & & & \\
\hline $2007-2008$ & 3 & 18 & 0.17 & $\begin{array}{l}3 \text { Bagarius spp., } \\
2 \text { Labeo spp. }\end{array}$ & & & & \\
\hline 2008-2009 & 6 & 24 & 0.25 & 2 Bagarius spp. & 14 & 43 & 0.33 & $\begin{array}{l}6 \text { chocolate mahseer, } \\
9 \text { Raiamas spp. }\end{array}$ \\
\hline 2009-2010 & 16 & 46 & 0.35 & 0 & 53 & 142 & 0.37 & $\begin{array}{l}22 \text { chocolate mah- } \\
\text { seer, } 10 \text { Raiamas spp. }\end{array}$ \\
\hline $2010-2011$ & 47 & 102 & 0.46 & 0 & 44 & 134 & 0.33 & $\begin{array}{l}43 \text { chocolate mah- } \\
\text { seer, } 3 \text { Raiamas spp. }\end{array}$ \\
\hline $2011-2012$ & 37 & 74 & 0.50 & $\begin{array}{l}1 \text { Tor spp., } 1 \text { Bagarius } \\
\text { spp., } 1 \text { Bangana spp. }\end{array}$ & 7 & 28 & 0.25 & $\begin{array}{l}2 \text { chocolate mahseer, } \\
2 \text { Wallago spp. }\end{array}$ \\
\hline
\end{tabular}

*The angling months of October-June, the peak angling season on these rivers before the arrival of the monsoon rains

The research was first explained to the each participant. Issues such as security, access and privacy of collected data were explained to each respondent. The interviewees chose whether to participate. Care was taken to allow respondents to express their opinions, and leading interviewees to an answer was avoided. The responses obtained from interviewees were recorded under the themes of conservation benefits, economic incentives and conservation concerns.

\section{Results}

\section{Catch data}

Two hundred records (147 fish landed and 53 unsuccessful angling events in a total of 357 hours of fishing) for 20042012 were obtained from the logbooks of the two angling associations on the Ramganga River. Fish landed included the golden mahseer, Bagarius spp., Labeo spp. and Bangana spp. (Table 1). For golden mahseer, mean annual CPUE ranged from $0.17(2007-2008)$ to $0.50(2011-2012)$ but there was no significant difference $(\mathrm{P}=0.43)$ across years, and weight landed (Fig. 1a) was 680-4,000 g (Table 1) and not significantly different across years $(\mathrm{P}=0.44)$.

Three hundred and ninety records ( 365 fish landed and 25 unsuccessful angling events in a total of 559 hours of fishing) for 1999-2012 were obtained from the logbooks of the angling association on the Jia Bharali River. Fish landed included the golden and chocolate mahseers, Raiamas spp. and Wallago spp. (Table 1). For golden mahseer, mean annual CPUE ranged from $0.17(1999-2000)$ to 0.45 (20032004; Table 1) and was significantly different across years $(\mathrm{P}=0.03$ ), and weight landed (Fig. $\mathrm{lb}$ ) was $2,400-7,000 \mathrm{~g}$ and significantly different across years $(\mathrm{P}=0.03)$. For chocolate mahseer, mean annual CPUE ranged from 0.07 (20112012) to 0.58 (1999-2000; Table 1 ) and was significantly different $(\mathrm{P}=0.001)$ across years, and weight landed (Fig. 1c) was 2,200-4,500 $\mathrm{g}$ and significantly different $(\mathrm{P}=0.02)$ across years.

\section{Stakeholders' views}

A total of 84 individuals (20 conservationists, 19 Indian catch-and-release anglers, 22 catch-and-release angling association workers, and 23 local residents) were interviewed. Their views are summarized in Table 2 under three themes.

Conservation benefits Fifty percent of conservationists indicated there was limited protection for fish but suggested that the presence of catch-and-release anglers deterred the use of illegal fishing methods such as 

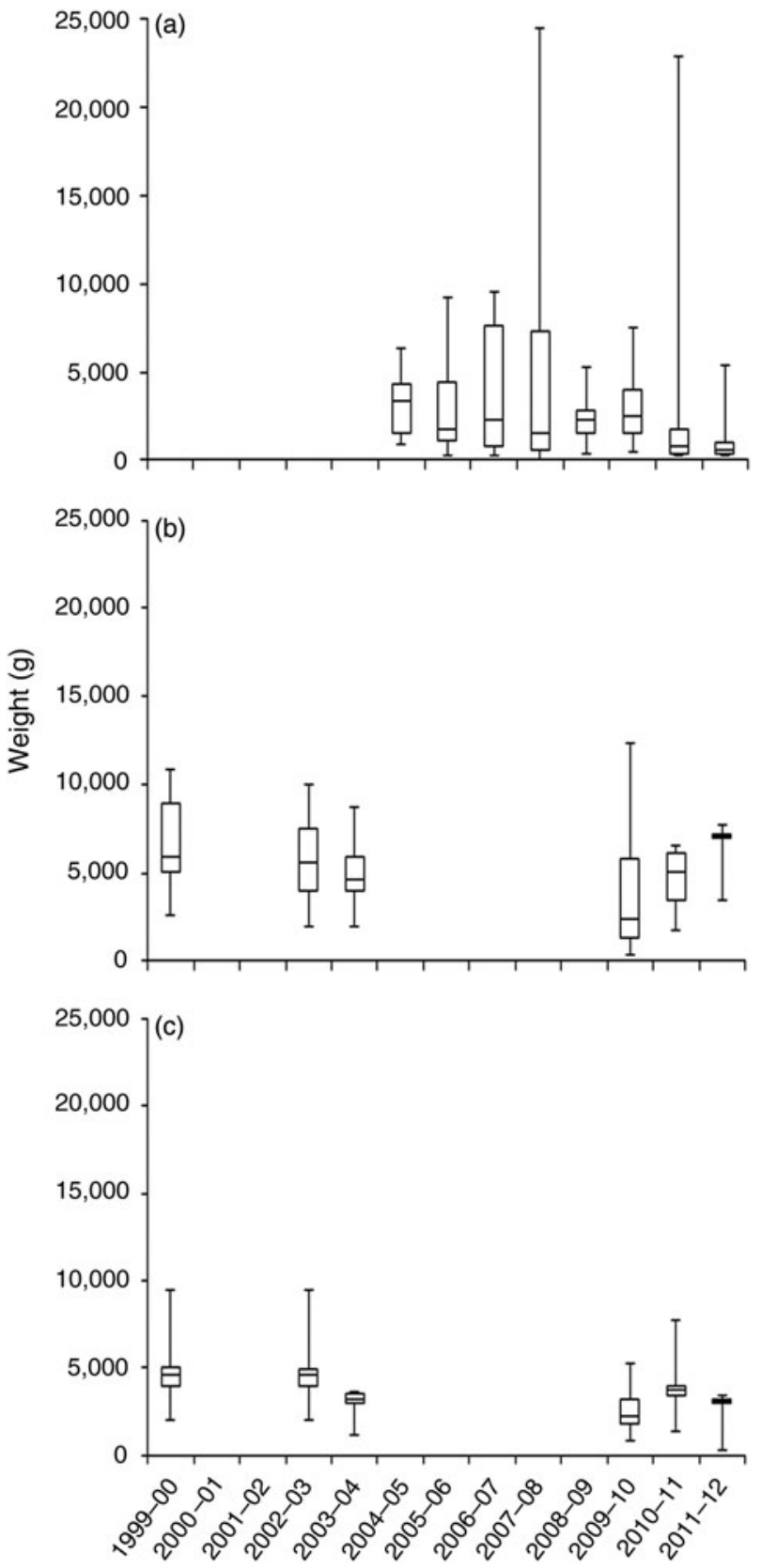

FIG. 1 Box-and-whisker plots of the weight of (a) golden mahseer Tor putitora caught during 2004-2012 on the Ramganga River, and (b) golden mahseer and (c) chocolate mahseer Neolissochilus hexagonolepis caught during 1999-2012 on the Jia Bharali River (the box contains the first and third quartiles and the band is the median, and the whiskers indicate the minimum and maximum values). Although the angling logbooks contained catch data for 2008-2009 for the golden and chocolate mahseer in the Jia Bharali river (Table 1) the data did not include the weight of individual fish, hence there are no box-and-whisker plots for this year in (b) and (c). A year is the angling months of October-June, the peak angling season on these rivers before the arrival of the monsoon rains.

dynamiting and poisoning. The other $50 \%$ of conservationists did not comment on this issue, either because of their lack of engagement with catch-and-release angling or because they did not wish to support the activity openly (as stated by them). All catch-and-release anglers indicated that catch-and-release angling was beneficial for mahseer and other fishes. Individuals in this group stated that economic opportunities generated through catch-and-release angling had brought together stakeholders, including local people. Anglers were also positive about how angling raises the profile of some fish, particularly golden mahseer. Amongst angling association workers, $82 \%$ indicated that catch-and-release angling had been crucial for the survival of mahseer (as angling prevented illegal fishing, which continued to occur upstream of angling locations), and $18 \%$ stated that the involvement of local stakeholders was critical for sustaining this approach. Amongst village members, $87 \%$ indicated that patrolling and guarding of river reaches had provided protection for the mahseer but $13 \%$ indicated that river reaches upstream from angling sites required urgent attention to ensure successful river and fish conservation.

Economic incentives Amongst conservationists, 75\% acknowledged that monetary benefits were provided to some local communities but $25 \%$ stressed that more money should percolate into local communities to secure support from stakeholders. All catch-and-release anglers indicated that local employment opportunities (e.g. catch-and-release angling guides, cooks, porters, cleaners) and economic benefits (e.g. through catch-and-release angling revenue) had increased substantially as a result of catch-and-release angling. Similarly, all association workers indicated there was considerable income for local people involved in catch-and-release angling, and there was a flow of revenue to local communities located near catch-and-release angling locations. Amongst village members, $83 \%$ indicated there were economic benefits to some village members (e.g. guides) but stressed they were not satisfied with the amount of money reaching their communities (although 17\% indicated that this amount was better than nothing).

Conservation concerns Amongst conservationists, 50\% indicated that although catch-and-release angling provided monetary incentives for local stakeholders, some inexperienced anglers visiting the region were causing harm to the river ecosystem (e.g. destroying vegetation to reach suitable angling sites) and to the fish (e.g. using unsuitable hooks, and long and poor handling of landed fish). Other conservationists were concerned with the absence of an appropriate attitude to conservation (e.g. lack of awareness of the target species) among some catch-and-release anglers. All catch-and-release anglers indicated that use of illegal fishing techniques was harming fish and threatening the sustainability of angling activities in the region. They wanted more patrolling by 
TABLE 2 Summary of the views of four groups of local stakeholders on the conservation benefits and economic incentives of, and conservation concerns for, catch-and-release angling on the Ramganga River.

\begin{tabular}{|c|c|c|c|c|}
\hline Criteria & Conservationists $(\mathrm{n}=20)$ & $\begin{array}{l}\text { Indian catch-and-release } \\
\text { anglers }(\mathrm{n}=19)\end{array}$ & $\begin{array}{l}\text { Angling association workers } \\
(\mathrm{n}=22)\end{array}$ & Local residents $(\mathrm{n}=23)$ \\
\hline $\begin{array}{l}\text { Conservation } \\
\text { benefits }\end{array}$ & $\begin{array}{l}\text { Presence of catch-and-release } \\
\text { anglers on river prevents } \\
\text { illegal fishing; some pre- } \\
\text { ferred not to comment }\end{array}$ & $\begin{array}{l}\text { Catch-and-release angling } \\
\text { beneficial for all fish species; } \\
\text { economic opportunities } \\
\text { bring key stakeholders } \\
\text { together; catch-and-release } \\
\text { angling raises profile of target } \\
\text { fish species }\end{array}$ & $\begin{array}{l}\text { Catch-and-release angling } \\
\text { crucial for survival of mah- } \\
\text { seer species; dynamite fish- } \\
\text { ing prevented at angling } \\
\text { sites; local stakeholders' } \\
\text { involvement critical for } \\
\text { conservation }\end{array}$ & $\begin{array}{l}\text { Regular patrolling \& } \\
\text { guarding of river reaches } \\
\text { provides protection to all } \\
\text { fish species; upstream } \\
\text { reaches of rivers need } \\
\text { attention to sustain } \\
\text { long-term conservation }\end{array}$ \\
\hline $\begin{array}{l}\text { Economic } \\
\text { incentives }\end{array}$ & $\begin{array}{l}\text { Some monetary benefits } \\
\text { provided to local communi- } \\
\text { ties; more money from } \\
\text { catch-and-release angling } \\
\text { should percolate into com- } \\
\text { munities, to help secure } \\
\text { support }\end{array}$ & $\begin{array}{l}\text { Local employment opportun- } \\
\text { ities \& economic benefits }\end{array}$ & $\begin{array}{l}\text { Considerable income for } \\
\text { local people involved in an- } \\
\text { gling activities; revenue for } \\
\text { local communities based } \\
\text { near angling locations }\end{array}$ & $\begin{array}{l}\text { Economic benefits to } \\
\text { some village members; } \\
\text { low satisfaction with } \\
\text { amount of money reach- } \\
\text { ing communities; the } \\
\text { money available for local } \\
\text { communities is better } \\
\text { than nothing }\end{array}$ \\
\hline $\begin{array}{l}\text { Conservation } \\
\text { concerns }\end{array}$ & $\begin{array}{l}\text { Some inexperienced anglers } \\
\text { causing harm to river eco- } \\
\text { systems; lack of conservation } \\
\text { awareness among some } \\
\text { catch-and-release anglers }\end{array}$ & $\begin{array}{l}\text { Illegal fishing techniques } \\
\text { harming fish species, with } \\
\text { sustainability of angling } \\
\text { under threat; more patrolling } \\
\text { by concerned authorities } \\
\text { required, \& harsher } \\
\text { punishments }\end{array}$ & $\begin{array}{l}\text { Use of dynamite for catching } \\
\text { fish damaging river ecosys- } \\
\text { tems; perpetrators need to be } \\
\text { brought to justice }\end{array}$ & $\begin{array}{l}\text { Pressures on upstream } \\
\text { river reaches needs } \\
\text { attention; tougher penal- } \\
\text { ties to deter illegal fishing } \\
\text { techniques; spreading } \\
\text { conservation awareness } \\
\text { of river ecosystem, tar- } \\
\text { geting local communities } \\
\text { living along rivers }\end{array}$ \\
\hline
\end{tabular}

forest officials and harsher punishments for offenders. All association workers indicated that the use of dynamite for catching fishes was damaging river ecosystems, and that those responsible should be prosecuted. Amongst local residents, $70 \%$ stated that unless pressures to upstream river reaches could be contained they would struggle to conserve downstream reaches, $13 \%$ believed that tougher penalties could deter the perpetrators, and $17 \%$ felt that awareness about river ecosystems should be encouraged by targeting local communities living beside rivers.

\section{Discussion}

Catch data recorded in logbooks are an inexpensive source of fishing data, especially in areas where regular scientific surveys have not been possible (Bishop et al., 2008; Sampson, 2011). Logbooks can also be a valuable source of data on the spatial distribution and amount of effort involved in fisheries (McGarvey et al., 2005; Cooper, 2006). Catch data from logbooks for catch-and-release angling on the Ramganga River showed that the interquartile range of the weight of golden mahseer decreased from 2010 to 2012 (Fig. 1a). On the Jia Bharali River there was a stable catch weight of both golden and chocolate mahseer during 2009-2012 (Figs 1b,c) but the interquartile range of weight varied during years and was smallest in 2011-2012, probably as a result of the decreased catch in these years (Table 1). However, with significant differences in CPUE and fish weight (also probably driven by annual variation in effort) during 1999-2012, there were no discernible patterns suggesting stable fish populations on the Jia Bharali River.

Although these data can provide information on fish population dynamics the data cannot be used to estimate population size. Therefore there are ongoing efforts to estimate population sizes of mahseer on the Ramganga River (N. Gupta, unpubl. data). The combination of quantitative population estimates and data from recreational catches can provide monitoring data and facilitate a citizen-science based approach for mahseer conservation (Bonney et al., 2009).

The robustness of the catch data from the catchand-release angling association logbooks could be questioned (Walsh et al., 2005; Marriott et al., 2013). However, despite the limitations of these data (Mosindy \& Duffy, 2007; Jansen et al., 2013) there are no reasons for the catch-and-release anglers to report data incorrectly. These data were recorded voluntarily and were not being collected for either management or stock assessment (Sampson, 2011), and logbooks are maintained by catch-and-release angling associations primarily to monitor whether target fish species are likely to be present at angling sites. The accuracy of these data ensures a sustainable catch-and-release angling business. 
The incorporation of local stakeholders is widely accepted as vital for the success of conservation (Granek et al., 2008), and engagement of and support from local stakeholders is crucial for the success of river conservation policies (Everard \& Kataria, 2011). More importantly, stakeholder participation in locally targeted conservation projects has the potential to protect fish (Pinder \& Raghavan, 2013). We found that conservationists were sceptical that catch-and-release angling associations could contribute to the protection of fish species, although some of the interviewees suggested that the presence of catch-and-release anglers on river banks discouraged illegal fishing practices. There was overall agreement amongst conservationists that if environmental rules are observed during catch-and-release angling, this activity could play an important role in fish conservation.

It was stressed by a majority of the interviewees that more profits from catch-and-release angling should reach local communities. To gain support from conservationists (which is key for the transfer of knowledge), catch-andrelease angling associations need to follow the guidelines for angling, and address the issue of improved profit-sharing for local communities.

The catch-and-release anglers emphasized that angling was advantageous to mahseers and to other fish species. Anglers believed this was because of the apex, ecological role of mahseer species in river ecosystems. It was added that catch-and-release angling had demonstrated the ability to bring key local stakeholders together whilst also raising the profile of game fish. Nevertheless, catch-and-release anglers wanted more patrolling by authorities, for controlling illegal activities and to help sustain catch-and-release angling.

Local people were concerned that upstream river stretches required improved protection to facilitate the conservation of the river stretches used for angling. The sympathies of this group towards conservation indicates their importance as stakeholders for river conservation. However, the concerns of some local people regarding profit sharing need to be examined by the catch-and-release angling associations, to ensure the long-term support of the local residents.

Despite the benefits it has been suggested that, in general, angling negatively affects fish communities and aquatic food webs and ecosystems (McPhee et al., 2002; Cooke \& Cowx, 2004; Arlinghaus, 2006; Granek et al., 2008). However, we believe that any shortcomings of catch-and-release angling depend on the history, laws, culture and economic environment of a country (Arlinghaus et al., 2007), and ecosystem management should take into account the benefits available from an ecosystem and how best to harness them for conservation strategies (Arismendi \& Nahuelhual, 2007) through economically viable use of natural resources (Zwirn et al., 2005). It is important to note that the angling experience of catch-and-release anglers depends on the well-being of the fishes they target (Arlinghaus, 2006; Granek et al., 2008). Any decline in target species will have an effect on the quality of the angling experience. More importantly, the economic viability of the angling industry is imperilled by threats to rivers and fish (Danylchuk \& Cooke, 2011), and therefore there has been a surge in collaborative approaches between catch-and-release anglers and stakeholders, often giving rise to successful fish conservation (Granek et al., 2008; Pereira et al., 2008; Cowx et al., 2010).

Although the mahseer species targeted by catchand-release anglers are categorized as threatened on the IUCN Red List, catch-and-release angling is not recorded as a threat in the species accounts. There is potential for catch-and-release angling to be a monitoring tool for fish conservation in India and elsewhere. Catch-and-release angling offers economic opportunities to local stakeholders and provides incentives for resource protection and maintenance of ecological integrity. It also helps generate local support through capacity building and sustainable development (Granek et al., 2008; Pinder \& Raghavan, 2013), and contributes to conservation by providing data (i.e. catch statistics, environmental monitoring) whilst also being a tool for the conservation of rivers and fish.

\section{Acknowledgements}

We thank the Directors and District Forest Officers of Corbett Tiger Reserve and Rajaji National Park for permissions, Sumantha Ghosh and Misty Dhillon for help with fieldwork, and Vinod Belwal, Sanjeev Paroriya and Assam (Bhoralli) Angling and Conservation Association. This study was funded by King's College London, UK.

\section{References}

Arismendi, I. \& Nahuelhual, L. (2007) Non-native salmon and trout recreational fishing in Lake Llanquihue, southern Chile: economic benefits and management implications. Reviews in Fisheries Science, 15, 311-325.

ARLINGHaUs, R. (2006) Overcoming human obstacles to conservation of recreational fishery resources, with emphasis on central Europe. Environmental Conservation, 33, 46-59.

Arlinghaus, R., Cooke, S.J., Lyman, J., Policansky, D., Schwab, A., SUSKi, C. et al. (2007) Understanding the complexity of catch-and-release in recreational fishing: an integrative synthesis of global knowledge from historical, ethical, social, and biological perspectives. Reviews in Fisheries Science, 15, 75-167.

Bishop, J., Venables, W.N., Dichmont, C.M. \& Sterling, D.J. (2008) Standardizing catch rates: is logbook information by itself enough? ICES Journal of Marine Science, 65, 255-266.

Bonney, R., Cooper, C.B., Dickinson, J., Kelling, S., Phillips, T., Rosenberg, K.V. \& Shirk, J. (2009) Citizen science: a developing tool for expanding science knowledge and scientific literacy.

BioScience, 59, 977-984. 
Cooke, S.J. \& Cowx, I.G. (2004) The role of recreational fishing in global fish crises. BioScience, 54, 857-859.

Cooper, A.B. (2006) A Guide to Fisheries Stock Assessment: From Data to Recommendations. Sea Grant College Program, University of New Hampshire, Durham, USA.

Cowx, I.G., Arlinghaus, R. \& Cooke, S.J. (2010) Harmonizing recreational fisheries and conservation objectives for aquatic biodiversity in inland waters. Journal of Fish Biology, 76, 2194-2215.

DanylChuK, A.J. \& Cooke, S.J. (2011) Engaging the recreational angling community to implement and manage aquatic protected areas. Conservation Biology, 25, 458-464.

Everard, M. \& Kataria, G. (2011) Recreational angling markets to advance the conservation of a reach of the Western Ramganga River, India. Aquatic Conservation: Marine and Freshwater Ecosystems, 21, 101-108.

Granek, E.F., Madin, E.M.P., Brown, M. A, Figueira, W., Cameron, D. S., Hogan, Z. et al. (2008) Engaging recreational fishers in management and conservation: global case studies. Conservation Biology, 22, 1125-1134.

Gupta, N. (2013) Reflections on a successful community conservation programme in Haryana, India. Journal of Development Management, 1, 117-122.

Gupta, N., Sivakumar, K., Mathur, V.B. \& Chadwick, M.A. (2014) The 'tiger of Indian rivers': stakeholders' perspectives on the golden mahseer as a flagship fish species. Area. Http://dx.doi.org/10. 1111/area.12124

Impson, N.D., Bills, I.R. \& Wolhuter, L. (eds) (2008) Technical Report on the State of Yellowfishes in South Africa. Report to the Water Research Commission by the Yellowfish Working Group. Water Research Commission, Pretoria, South Africa.

Jansen, T., Arlinghaus, R., Als, T.D. \& Skov, C. (2013) Voluntary angler logbooks reveal long-term changes in a lentic pike, Esox lucius, population. Fisheries Management and Ecology, 20, 125-136.

Jena, J. K. \& Gopalakrishnan, A. (2012) Aquatic biodiversity management in India. Proceedings of the National Academy of Sciences, India Section B: Biological Sciences, 82, 363-379.

Lakra, W.S., Mohindra, V. \& Lal, K.K. (2007) Fish genetics and conservation research in India: status and perspectives. Fish Physiology and Biochemistry, 33, 475-487.

Marriot t, R.J., O’Neill, M.F., Newman, S.J. \& Skepper, C.L. (2013) Abundance indices for long-lived tropical snappers: estimating standardized catch rates from spatially and temporally coarse logbook data. ICES Journal of Marine Science. Http://dx.doi.org/10. 1093/icesjms/fst167

McGarvey, R., Punt, A.E. \& Matthews, J.M. (2005) Assessing the information content of catch-in-numbers: a simulation comparison of catch and effort data sets. Fisheries Assessment and Management in Data-Limited Situations, 5, 635-682.

McPhee, D.P., Leadbitter, D. \& Skilleter, G.A. (2002) Swallowing the bait: is recreational fishing in Australia ecologically sustainable? Pacific Conservation Biology, 8, 40-51.
Mosindy, T. \& Duffy, M. (2007) The use of angler diary surveys to evaluate long-term changes in muskellunge populations on Lake of the Woods, Ontario. Developments in Environmental Biology of Fishes, 79, 71-83.

Nautiyal, P., Babu, S. \& Behera, S. (eds) (2013) Proceedings of the workshop on mahseer conservation in India: status, challenges and the way forward. WWF-India, New Delhi, India.

Pereira, J.M.A, Petrere, Jr, M. \& Ribeiro-Filho, R. (2008) Angling sport fishing in Lobo-Broa reservoir (Itirapina, SP, Brazil). Brazilian Journal of Biology, 68, 721-731.

Pinder, A.C. \& Raghavan, R. (2013) Conserving the endangered mahseers (Tor spp.) of India: the positive role of recreational fisheries. Current Science, 104, 1472-1475.

Ribot, J.C., Agrawal, A. \& Larson, A.M. (2006) Recentralizing while decentralizing: how national governments reappropriate forest resources. World Development, 34, 1864-1886.

SAMPson, D.B. (2011) The accuracy of self-reported fisheries data: Oregon trawl logbook fishing locations and retained catches. Fisheries Research, 112, 59-76.

SARIN, M. (2005) Laws, lore and logjams: critical issues in Indian forest conservation. Gatekeeper, 116, 2-24.

Sarkar, U.K. \& Bain, M.B. (2007) Priority habitats for the conservation of large river fish in the Ganges river basin. Aquatic Conservation: Marine and Freshwater Ecosystems, 17, 349-359.

SARKAR, U.K., PATHAK, A.K. \& LAKRA, W.S. (2008) Conservation of freshwater fish resources of India: new approaches, assessment and challenges. Biodiversity and Conservation, 17, 2495-2511.

SCHINDLER, D.E. (2007) Fish extinctions and ecosystem functioning in tropical ecosystems. Proceedings of the National Academy of Sciences of the United States of America, 104, 5707-5708.

Walsh, W.A., Ito, R.Y., KaWAmoto, K.E. \& MCCracken, M. (2005) Analysis of logbook accuracy for blue marlin (Makaira nigricans) in the Hawaii-based longline fishery with a generalized additive model and commercial sales data. Fisheries Research, 75, 175-192.

Zwirn, M., Pinsky, M. \& RAhr, G. (2005) Angling ecotourism: issues, guidelines and experience from Kamchatka. Journal of Ecotourism, $4,16-31$.

\section{Biographical sketches}

Nishikant Gupta is interested in river and fish conservation in India. PrAKASH NAUTIYAL's interests include conservation of mahseer species, and aquatic biodiversity and flow assessment for Himalayan Rivers. ATUl BORgOhain is interested in the potential of angling tourism in India. K. SIVAKUMAR's interests include fish and avian ecology, island ecology, marine biology, invasive species and Antarctic wildlife. VINOD MATHUR's interests include biodiversity conservation, environmental and strategic impact assessment, biodiversity informatics and natural heritage conservation. MiCHAEL CHADWICK's interests include understanding how ecosystem structure and function respond to changes in environmental conditions. 